\title{
Specific Periodization for the Volleyball: Organize the Ball Training According to the Skill Injury Level
}

ISSN: 2577-1914

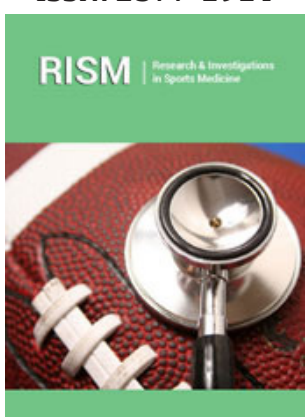

*Corresponding author: Nelson Kautzner Marques Junior, Department of Physical Education, Santiago, Chile

Submission: 眥 December 16, 2019

Published: 門December 22, 2020

Volume 7 - Issue 2

How to cite this article: Nelson Kautzner Marques Junior. Specific Periodization for the Volleyball: Organize the Ball Training According to the Skill Injury Level. Res Inves Sports Med, 7(2), RISM.000660. 2020. DOI: $10.31031 /$ RISM.2020.07.000660

Copyright@ Nelson Kautzner Marques Junior. This article is distributed under the terms of the Creative Commons Attribution 4.0 International License, which permits unrestricted use and redistribution provided that the original author and source are credited.

\author{
Nelson Kautzner Marques Junior* \\ Department of Physical Education, Chile
}

\begin{abstract}
The objective of the article was to explain this periodization model that organizes the ball training according to the skill injury level and the skilled effort. Performance sports studies determined that more than $50 \%$ of injuries are caused by training error. Volleyball literature determined that the skills with more effort during the volleyball match cause more injuries to the volleyball player. Specific periodization for the volleyball the coach organizes the training of the volleyball skills according to the injury level and skill effort, but the session is also organized to improve technical and tactical components. Specific periodization for the volleyball the coach organizes the ball training with three contents (sequence of the skill defined, skill effort and skill injury) and the session is according to the objective of the session. In conclusion, the ball training (technical and situation training) the coach structure the session with a subjective control of the skilled effort and of the skilled injury, but the research needs to conduct studies for determining the benefits of this model for the volleyball players.
\end{abstract}

Keywords: Training; Injury; Volleyball; Sports; Periodization; Collective sports

\section{Introduction}

Performance sports studies determined that more than $50 \%$ of injuries are caused by training error [1]. The reasons for the injuries are several, for example, the coach does not adequately prepare the training load [2,3] the athletes perform many jumps during the sessions [4], the sportsmen practice the sessions more than 2 hours and 30 minutes [5] and other motives. Volleyball literature determined that the skills with more effort during the volleyball match cause more injuries to the volleyball player [6]. The volleyball skills with a jump (jump serve, jump set, attack and block) occur the greatest efforts $[7,8]$ and the players get more injuries when they practice these skills $[9,10]$. Therefore, this is a problem of the volleyball for the coach elaborates on the training. How the coach can elaborate on the volleyball training to try to reduce the number of injuries? In 2011 began to be elaborated the specific periodization for the volleyball [11], this model the coach organizes the training of the volleyball skills according to the injury level and skill effort, but the session is also organized to improve technical and tactical components $[12,13]$. Therefore, this is a new way to organize the ball training. Marques Junior [14] defined this periodization model: "specific periodization for the volleyball is a content of the sports training that has the objective of organizing the sessions of the technical and tactical training and of the physical training with the objective of provide sports success through of the competitive and cause fewer injury occurrences during the season competitive". Then, the objective of the article was to explain this periodization model that organizes the ball training according to the skill injury level and the skilled effort.

\section{Ball Training Organization}

Periodization is a content of the sports training with the objective of organizing all the training of a team [15,16]. There are several periodization models [17-19], but a model for the volleyball that organizes the session according to the skill injury level and the skilled effort is the first periodization model [14]. Specific periodization for the volleyball the coach organizes the ball training with three contents and the session is according to the objective 
of the session [7]. The first content is the sequence of the volleyball skill defined during the game. The serve starts the match, the reception and the set practice the construction and the offensive development, the attack has the objective of causing a point, the block is important to practice a point or avoid the point and defense has the objective of starts the counterattack. Therefore, this content the coach uses in the game situation training and in the game training. The second content is the volleyball skill effort and was determined by a heart rate that the jump skill has the greatest effort and the overhand serve has light effort [14]. The third content is the level of volleyball skill injury and was determined that the skills with the greatest effort have more injury and the skills with light effort have less injury. The second and third content the coach uses during the technical training and in the game situation training. But the game training the coach does not use two contents because this session the control of the skilled effort and of the skilled injury is difficult [6]. (Figure 1) illustrates the three contents for the coach structure the ball training. The technical training and the game situation training the coach should use the content of (Figure 2) for structure the ball training [6,14]. For example, a volleyball coach has the objective of improve the skills of a young volleyball team of 13 to 14 years old and used the content of (Figure 2) to structure the ball training. The coach prescribes the technical training of five skills (set, reception or pass, overhand serve, attack, and block) for 10 minutes each skill with the blocked practice of motor learning.

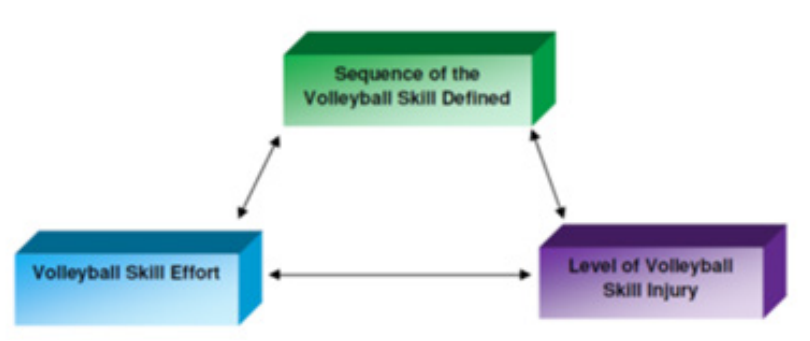

Figure 1: Interconnected contents for the volleyball coach prescribes the ball training.

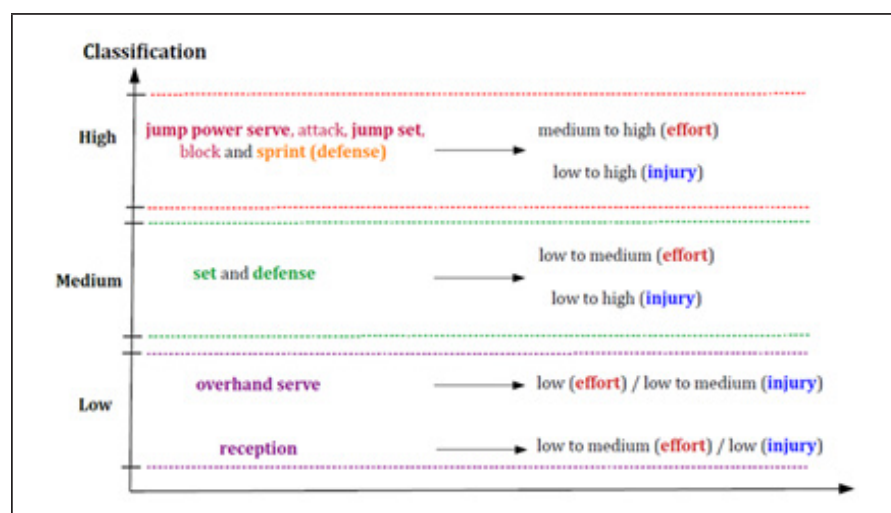

Figure 2: Content for prescribing the ball training.

In double, the players practiced the set because the classification of this skill is medium (effort and injury), an interesting skill for start the session. After this exercise, the players practiced the double block with the objective of improving the coordination of this skill. The block has a classification high (effort and injury), this skill and others are subjectively classified. The third exercise the young players practiced the overhand serve because the low classification (effort and injury) is safer after high work. Therefore, the young players practiced an active rest and with low level of injury. The fourth skill was the attack, the players threw the ball up and practiced the attack in zone 2, 3 and 4 of the court. This exercise is with a high classification (effort and injury). After high training stress and with a high level of injury-was the attack training, the young volleyball players practiced skill of low classification. In double, the players practiced the pass that is a work of low classification. (Figure 3) illustrates this work during technical training. Work classification of the skills of (Figure 2) is a subjective control about the skilled effort and of the skilled injury for the coach has a parameter for structure the ball training before of the players practiced the session [6]. After the technical training, the coach shows for the young volleyball players the faces scale of the subjective perception of effort adapted of Foster for determine the intensity [20] and the faces scale of the subjective perception of the muscle soreness of the physical effort of the sport and of the physical activity for determine the fatigue [21]. The result of the faces scale adapted of Foster the coach can determine the training load and the Marques Junior article [13] explained in detail the calculations for the reader to determine the training load. The content about the micro cycle and the mesocycle the reader can consult the Marques Junior article [12]. However, subjective control (effort and injury) of the example of the technical training this article needs of more studies because the specific periodization for the volleyball is a theory [14] because only a study was practiced with this model [22]. The same procedure the coach practices for he prescribes the game situation training.

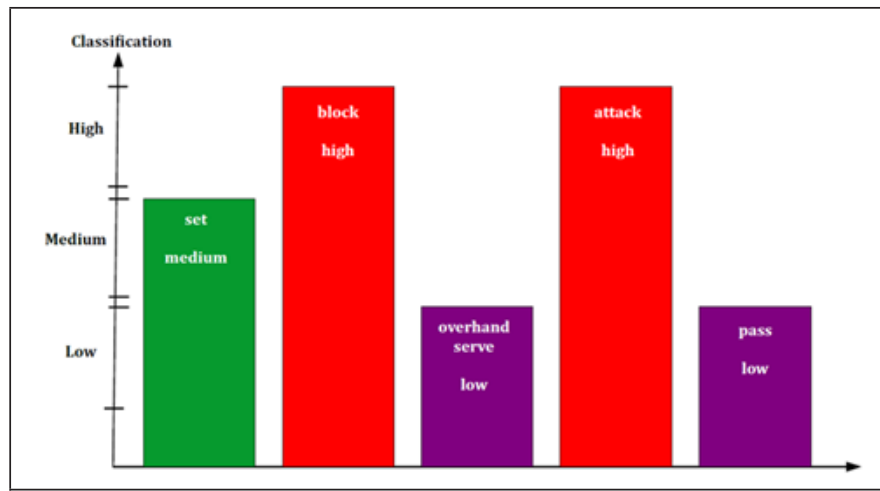

Figure 3: Subjectively classified of the work determined by the coach.

\section{Conclusion}

The ball training (technical and situation training) the coach structure the session with a subjective control of the skilled effort and of the skilled injury, but the research needs to conduct studies for determining the benefits of this model for the volleyball players.

\section{References}

1. Marques Junior N (2001) Volleyball: Applied biomechanics and strength training. GPS, Brazil. pp. 1-87.

2. Carey D, Blanch P, Ong K, Crossley K, Crow J, et al. (2017) Training loads and injury risk in Australian football-differing acute: Chronic workload ratios influence match injury risk. Br J Sports Med 51(16): 1215-1220. 
3. Gabbett T (2016) The training-injury prevention paradox: Should ath letes be training smarter and harder? Br J Sports Med 50(2): 1-9.

4. Visnes H, Aandahl H, Bahr R (2013) Jumpers knee paradox-jumping ability is a risk factor for developing jumpers knee: A 5-years prospective study. Br J Sports Med 47(8): 503-507.

5. Marques Junior N (2014) Specific periodization for volleyball: Updating the content. Rev Bras Prescr Fisio Exerc 8(47): 453-484.

6. Marques Junior N (2019) Specific periodization for the volleyball: A training organization with ball and the physical training. Rev Bras Prescr Fisio Exerc 13(81): 58-69.

7. Marques Junior N (2018) Specific periodization for the volleyball: A training organization. MOJ Sports Med 2(3): 108-111.

8. Horta T, Filho B, Miranda R, Coimbra D, Werneck F (2017) Influence of vertical jumps on perception of internal volleyball training load. Rev Bras Med Esp 23(5): 403-406.

9. Bere T, Kruczynski J, Veintimilla N, Hamu Y, Bahr R (2015) Injury risk is low among world-class volleball players: 4-year data from the FIVB injury survillance system. Br J Sports Med 49(17): 1132-1137.

10. Olmedo J, Tomas A (2015) Injuries and pathologies in beach volleyball players: A systematic review. J Hum Sport Exerc 10(4): 936-948.

11. Marques Junior N (2011) Periodization models for sports. Rev Bras Prescr Fisio Exerc 5(26): 143-162.

12. Marques Junior N (2017) Specific periodization for volleyball: Use of the macrocycle elaborated in Excel $_{\mathbb{Q}^{\circ}}$. Rev Activ Phys Ci 9(2): 56-77.

13. Marques Junior N (2017) Specific periodization for volleyball: Updating the content of the training load. Rev Observatorio Dep 3(4): 32-60.

14. Marques Junior N (2019) Specific periodization for volleyball: A theory that deserves research. Olimpia 16 (57): 150-160.

15. Issurin V (2008) Block periodization: Breakthrough in sports training. In: Ultimate Athlete Concepts, Michigan, USA. pp. 1-226.

16. Marques Junior N (2019) Benefits of the Russian revolution. Germinal Marx Educ Debate 11(1): 210-221.

17. Issurin V (2016) Benefits and limitations of block periodized training approaches to athletes preparation: A review. Sports Med 46(3): 329338.

18. Matveev L (1977) Periodization of sports training. INEF, Spain.

19. Verkhoshanski Y (1999) Principles for a rational organization of the training process aimed at speed development. Rev Trein Desp 4(1): 1-8.

20. Marques Junior N (2017) Reliability of the face scale of the subjective perception of effort adapted from Foster: A study in master volleyball. Rev 100-Cs 3(1): 29-42.

21. Marques Junior N (2019) Problem of the classification of the muscle soreness level with the volleyball scale. MOJ Sports Med 3(2):42-50.

22. Marques Junior N (2016) Injury to the calcaneal tendon of a volleyball athlete: Experience report. Rev Bras Prescr Fisio Exerc 10 (57): 29-66.

For possible submissions Click below: 